\title{
LEGAL STUDIES IN SECONDARY \\ SCHOOLS: THE NEW SOUTH WALES \\ EXPERIENCE
}

\author{
PATTY KAMVOUNIAS*
}

\section{INTRODUCTION}

The extraordinary growth and popularity of legal studies in New South Wales secondary schools clearly demonstrates the interest of school students in the law and confirms that legal education is not the exclusive domain of the universities. Much of the literature on legal education focuses on tertiary legal education with very little attention being given to legal education in secondary schools. ${ }^{1}$ What exactly is being taught in the secondary school legal studies courses? How and by whom should such courses be taught? In this article, I outline the content of the legal studies courses in New South Wales and argue that the current courses and the plans for further developments are overly ambitious for several reasons, including, that the course content has not been kept to reasonable limits and that in some instances may be overly technical. As part of my argument, I discuss the assistance currently offered to legal studies teachers to illustrate the ambitious nature of the courses in New South Wales. Secondary school teachers are not lawyers, yet they are being called upon to teach "law" or more correctly, to teach "about the law". Being "teachers" they know how to teach but now they are necessarily concentrating on what to teach. 


\section{WHY TEACH LEGAL STUDIES IN SECONDARY SCHOOL?}

Most commentators agree that legal studies courses have a legitimate place in secondary schools. The main reasons advanced for this are: education in survival skills, ${ }^{2}$ citizenship Education, ${ }^{3}$ and education in critical thinking. ${ }^{4}$ Other reasons for including legal studies courses in the secondary school curriculum include: the value of a liberal education, ${ }^{5}$ delinquency prevention, ${ }^{6}$ and ethics education. ${ }^{7}$ Perhaps, legal studies should be taught simply to overcome what has been described as "a staggering ignorance of matters legal." 8 Despite these views, some still believe that legal studies courses are inappropriate for secondary schools. Given that legal education has in the past generally only been available to lawyers and to students who studied law with a view to becoming lawyers, Lindgren has noted that some lawyers "may feel threatened by the notion of legal education for lay people, particularly where the instigation and control of such activity lies elsewhere than within the legal profession." ${ }^{\text {9 }}$ Tertiary institutions may also be reluctant to accept that some form of legal studies can be taught successfully in schools; this was one of the early obstacles to the introduction of the legal studies course in Victoria. ${ }^{10}$

Dobson $^{11}$ takes the view that a little knowledge, far from being a dangerous thing, is better than no knowledge at all. He stresses, however, that -

“... much depends upon what exactly is taught and the approach that is taken. The teaching needs to inculcate caution; it should not pretend to make children experts and it should lead them to avoid the dogmatic or glib answer. They should be taught to doubt and to question. However all of this can be said of any education, whatever the subject being taught. It certainly does not ... [mean that law is] a peculiar subject too specialised, difficult or esoteric to be allowed into the understanding of ordinary folk." 12

Course content then is all important, as is the approach taken to teaching a legal studies course. There are basically two options when deciding the approach to be taken to teaching law in schools. Legal studies courses may either be rule based "black letter law" courses or broader conceptual courses focussing on fundamental principles and law as regulation of society. Again, most 
commentators reject giving secondary school students a "boiled down version of what undergraduates ... have traditionally been given." 13 Teaching such students a lot of detailed rules is not appropriate "either from a jurisprudential or from an educational point of view. There is more to law than substantive rules and there is more to legal education, at any level, than learning those rules.”14

\section{BACKGROUND}

Justice Michael Kirby, an advocate of Legal Studies in schools for many years, recently commented that:

“... If the law moves at a languid pace, the educational establishment is not much better .... Half a generation of school students have passed through the educational system since we began calling for the teaching of Legal Studies in schools in this state. The ways of curriculum reform are wondrously slow." 15

The Law Foundation of New South Wales established the Higher School Education Law Project (HELP) in early 1975 to develop curriculum materials and examine methods of introducing and teaching law in high schools. ${ }^{16}$ HELP did not favour the study of particular areas of substantive law nor did it aim to introduce Legal Studies as a subject in its own right. Instead, HELP aimed at giving a "legal dimension” to subjects already being taught —

"to get students to examine the law as it relates to various themes or topic areas, e.g. the environment, jobs, consumerism, industrial relations, etc., ... in such a way we feel the non-legally trained teacher, supported by resources and possibly some familiarisation in, preferably at both pre-service and in-service stages of their teaching careers, can meet the challenge of raising the average ability student's awareness and understanding of the relationship between legal principles and processes and the everyday reality of living in our changing society"17

The current Legal Studies course is a separate subject in its own right but it certainly reflects this philosophy. The debate about the level of introduction of legal studies, and the degree of detail in which it would be taught held up its introduction for many years.

The Board of Senior School Studies had allowed individual schools to introduce courses as "Other Approved Studies" to cater for student interest; grades were recorded on the Higher School Certificate ("HSC”) but did not count towards a student's "best ten aggregate mark" — some law related subjects had been taught in New South Wales schools under this scheme from the early 
1970s. ${ }^{18}$

In the early 1980s a working party was established through the efforts of the Legal Education Teachers Association (LETA) and it submitted the idea of a separate Legal Studies course to the Board. The Board accepted this suggestion in 1985 and established a committee charged with the task of setting up the syllabus. The syllabus committee was made up of representatives from a number of universities, the Department of Education, independent and Catholic Schools, the Teachers' Federation and parents groups. Interestingly, the legal profession was not directly represented on the Committee; the Law Society of New South Wales did not have a representative on the committee but was granted observer status, so it did have the opportunity to have some input. ${ }^{19}$

The first syllabus committee produced the syllabus for Legal Studies in Years 11 and 12 that was finally approved by the New South Wales Board of Secondary Education in August 1988. The 2 Unit Legal Studies course was designed to be taught over 240 hours of timetabled school time over two years. The syllabus was introduced in 1989 to those schools that wanted to offer it and the first HSC examination was held in 1990. Almost 2,000 students sat the first HSC Legal Studies examination; approximately 7,000 students sat the examination in 1991 and more than 10,000 sat the examination in $1992 .^{20}$

The New South Wales Board of Studies recently undertook a review of the Legal Studies course and in September 1993 approved a new syllabus for the 2 Unit course for implementation in Year 11, 1994.

The Board offers courses of study for the HSC at 1, 2, 3 or 4 Unit level with the 3 and 4 Unit levels reflecting a higher standard of achievement. In late October 1992, the Minister for Education approved the introduction of a 3 Unit Legal Studies Course for Year 11 in 1993 and Year 12 in 1994. In view of the history of the 2 Unit course it was surprising that the Board expected a 3 Unit course to be approved in such a short time. In March 1993 the Board published a writing brief for the 3 Unit syllabus and invited comment. Later that year it approved a pilot 3 Unit syllabus for implementation in 1994. 


\section{THE ORIGINAL 2 UNIT LEGAL STUDIES SYLLABUS}

The rationale of the course is stated as follows:

"The course is designed to develop an understanding of the law appropriate for all. The syllabus is NOT designed to prepare students for further study in law or to advise others about the law BUT rather to prepare them to participate effectively in everyday life."21

Goldring notes that the syllabus is designed for all students, not only those going on to tertiary study and certainly not for those who hope to become lawyers,

"but rather is an exercise in community education about the law. It is concerned with themes and concepts which are examined through the study of particular areas of law". ${ }^{22}$

As stated in the syllabus document, Legal Studies aims to assist students to:

- understand the functions and limits of law in resolving conflict and regulating behaviour in society;

- develop an understanding of the history and operations of the Australian legal system;

- communicate effectively about the law in order to participate more effectively in Australian society;

- appreciate that the law is closely related to one's personal life and relates to everyone's rights and responsibilities in Australian society;

- develop a positive, informed and unprejudiced but questioning attitude to law and legal matters. ${ }^{23}$

The syllabus also contains a very long list of objectives with respect to knowledge, skills, attitudes and values. ${ }^{24}$ For example, students should be able, inter alia, to develop the language, research and analytical skills required for understanding and evaluating legal issues and to participate effectively in resolving legal disputes through formal and informal processes (such as negotiation and mediation). ${ }^{25} \mathrm{~A}$ Legal Studies study guide ${ }^{26}$ discusses the skills necessary to be a good Legal Studies student; such a student should "understand basic legal terms; identify legal issues; develop research skills; apply legal principles; become 'legally literate'.”

\section{Course Content}

The syllabus document is very detailed. Each topic is discussed 
in terms of the area of study (this indicates the general topic as well as specific knowledge and skills to be covered); issues (these raise questions for discussion, linking areas of knowledge to the themes of the course); and notes and comments (this indicates possible methodologies and aspects of the subject matter requiring emphasis). ${ }^{27}$ The syllabus stresses themes; students are not expected to acquire a detailed knowledge of the law - "they are to concentrate on broader issues and avoid becoming distracted by detailed rules and regulations." ${ }^{28}$ The central theme of the course is stated to be: "the inter- relationship between the concepts of Justice, Law and Society". ${ }^{29}$ Diekman notes that the central theme could almost be the subtitle of the course; every topic studied is important only because of the light it sheds upon the theme. ${ }^{30}$ Subsidiary themes which are used to develop the central theme are:

- history, continuity and change

- conflict and co-operation

- culture and values

- human rights, equality and discrimination

- legal processes and institutions. ${ }^{31}$ Boyd advises teachers "to avoid teaching it as a law course and to concentrate on issues and the themes." 32 Indeed, the Board states that "[as] the methodology for this subject, teachers are expected to relate the content material to the central and subsidiary themes, using their experience and discretion as to the particular approaches to be used”. 33

One of the problems facing legal studies teachers is not knowing how to interpret the syllabus. As an approach to the course, Roberts has stated that the emphasis must be on the themes first and the content second -

"with this approach the three options and the one case study ... cannot be taught as isolated units. Cross-references, reflecting the themes, are essential to gain a full understanding of the issues"34

Teachers must plan their classes well in advance. Issues in the introductory and concluding topics must be referred to throughout the other areas of study with the result that at the very beginning of Year 11, students and teachers need to know what they will be concentrating on at the end of Year 12.

The themes are to be explored through studying five topics. The introductory topic — The Legal System — is compulsory; it is 
designed to give students a background and basic vocabulary so that they can understand the later areas of study and to provide the basic skills and concepts required for the remainder of the course. ${ }^{35}$ Students are then required to study three topics selected from a list of six options: Consumers and the Law; ${ }^{36}$ Crime and the Law; ${ }^{37}$ Environment and the Law; ${ }^{38}$ the Family and the Law; ${ }^{39}$ Housing and the Law; ${ }^{40}$ and the Workplace and the Law. ${ }^{41}$

Students must then in the compulsory concluding topic, consider the nature and meaning of Law and Justice. This topic is divided into three inter-related parts:

Part I - The nature of law and justice;

It is envisaged that in this part of the course:

"inquiring minds will be stimulated and excited by the ideas of some of history's great thinkers. Ultimately, however, they must learn to think for themselves. Grappling with the concept of justice they will learn to appreciate the enormous complexity of the task confronting lawmakers .... Armed with some philosophical awareness students then go on to examine ..."

Part II — The individual and the state; and

Part III - Case studies where students are to choose one of a number of disadvantaged groups ${ }^{43}$ and look at how and why these people have been denied justice under the law:

"Using the skills and insights developed throughout the course, students will be able to deal with the issues raised in a manner which is both sensitive and informed". 44

The course can be described in one word: ambitious. The objectives, the content, the methods of assessment are all extremely ambitious.

The content in a course said to be designed for all and not only those contemplating tertiary study is overly technical. Justice Kirby has noted that the "large slabs of legislation relevant to consumers' rights may get down to a level of detail that even experienced judges and lawyers find it difficult to remember. ${ }^{45}$

The concluding compulsory topic on law and justice appears particularly ambitious: it looks very much like a university jurisprudence course. Although it is stated in the syllabus document that students are not required to conduct any sort of detailed study of legal theory, reference is also made to a number of established schools of thought such as positivism, utilitarianism and natural 
law and to major writers such as Bentham, Austin and Marx. ${ }^{46}$ Is this within the capabilities of school students who are doing the course "to prepare them to participate effectively in everyday life"?

\section{Assessment}

The final examination in Legal Studies is based on the 1988 syllabus document and, like all HSC papers, is externally set: $20 \%$ is allocated to multiple choice questions based on the compulsory units; $80 \%$ is allocated to essays on the optional topics and on the concluding topic with a focus on the case study. The multiple choice component of the examination could be the cause of some concern. There are a limited number of ways to ask multiple choice questions on the compulsory topics; short answer questions may be a preferred option. The Board distributes guidelines as to how examination essays are ranked. It is interesting to note that the “ A answer is that which exhibits "evaluation/logical argument and valid interpretation". ${ }^{47}$ Are the essay questions being asked consistent with the rationale of the course? It seems not. The HSC examiners report that students have problems with evaluative questions. How can a student be expected, for example, to "evaluate the approach that consumer law has taken to ... at least three specific problem areas such as faulty or unsuitable goods and services, finance, advertising, and product standards ..."48 if they do not have a good working knowledge of the law in the relevant area? Although not a rule based course, in order to answer the essay questions a detailed knowledge of rules appears to be required. Furthermore, the HSC examiners are also critical of the essays in that the students are not referring to appropriate cases!

The syllabus also sets out guidelines for school assessment of student achievement and states that a range of assessment instruments must be used, including mock trials and mini-trials. ${ }^{49}$ Is this yet another ambitious aspect of the course? Are secondary school teachers capable of devising and assessing this type of exercise?

Le Brun warns that:

"... we must check that the aims and objectives of our courses are realistic, achievable and compatible, and are devised, examined and criticised by individuals who have a solid foundation in law in context, and law, if our curriculum is so designed. One must bear in mind, 
however, that as the balance between rule orientation and a contextual understanding of the law has yet to be satisfactorily achieved in law schools, it would be amazing were it successfully managed in Australian secondary schools were it attempted."

There is also much emphasis placed on the HSC examination paper itself, i.e. in in-services, textbooks, study guides, and so on. Students and teachers are advised to include in their study programme a study of the actual HSC examination papers from previous years and the examiner's reports in relation thereto.

"Familiarity with past papers is so important."

The form and content of prior examinations seems to dictate what happens in the classroom.

Le Brun notes that:

“... legal studies teachers who are untrained in law will have to place an even greater reliance on secondary sources and authorities, the established curriculum, or a particular teaching context than ever before. In order to cope with any understandable feelings of inadequacy ... such teachers may reach for past examination papers and teach to them ... "52

Le Brun argues that having teachers who lack confidence in the subject matter they teach and who use examinations to determine what should be taught is inconsistent with good learning. In these circumstances, teachers are unable to give sufficient attention to the student learner and are "pollut[ing] the educational enterprise because students learn ... that education involves 'beating the system', whether that system be the award of HSC grades or otherwise". ${ }^{53}$

As is the standard procedure for all new courses, the 2 Unit Legal Studies syllabus was reviewed by the Board of Studies in 1992. A survey was sent to all schools in New South Wales to see what was happening with the 2 Unit course and whether there was sufficient demand for a 3 Unit course. The results of the survey yielded some interesting results. ${ }^{54}$ Teachers did not always teach the course in the order suggested by the syllabus nor did they spend the recommended time on each section. Of the optional topics, the most popular by far were Crime and the Law and the Family and the Law; of the case studies, Aborigines and Women were the most popular choices. This choice of topics was, surprisingly, not the result of staff expertise or available resources but, due to student 
interest. Most responses favoured maintaining the course aims and objectives, range of topics and school assessment guide, but there were significant numbers favouring a reduction in the compulsory and an expansion in the optional topics. Most responses also thought the HSC exam format was appropriate but a not insignificant number, i.e. 34\%, did not or were unsure. The overwhelming majority of responses believed a 3 Unit course would receive student support.

\section{THE REVISED 2 UNIT LEGAL STUDIES SYLLABUS}

As already noted, the Board of Studies has approved a new 2 Unit syllabus for implementation in 1994. The rationale, aims, objectives, central themes, subsidiary themes, range of topics and methods of assessment are virtually identical to those in the syllabus approved in 1988; what is very different is the course structure. Instead of one course designed to be taught over two years, the course sequence for Legal Studies now includes a Preliminary Course and an HSC course. ${ }^{55}$

The Preliminary course consists of three compulsory topics that are to be studied in the order listed in the syllabus, namely, The Legal System; The Legal System in Practice: Crime and the Law; and The Effectiveness of Criminal Law. ${ }^{56}$ Assessment of student achievement in the Preliminary course is school based and is not subject to moderation for the HSC and therefore will not contribute to the HSC Assessment mark. ${ }^{57}$ The syllabus states that "[s]uch formal assessment conducted during the Preliminary course becomes a learning experience for the student whose performance should therefore benefit when similar techniques are applied in the HSC Course for final assessment purposes. ${ }^{58}$

In the HSC Course, a further two compulsory topics and two optional topics are to be completed. The compulsory introductory topic is Overview of the Australian Legal System. The overview is followed by two optional topics examining the law in five specific areas. The optional topic areas are the same as in the 1988 syllabus (with the exception of the topic Crime and the Law). The concluding topic of Law and Justice is also compulsory as it was in the 1988 syllabus. ${ }^{59}$

The new syllabus clarifies the order that the topics are to be studied. The restructuring of the course has also reduced the 
optional and increased the compulsory areas of study. This is contrary to the changes suggested by the respondents to the 2 Unit syllabus review survey.

Furthermore, the restructured course places a much greater emphasis on criminal law. Although Crime and the Law was one of the popular optional topics, it now becomes a compulsory topic taking up $25 \%$ of total course time. ${ }^{60}$ The additional time allocated to criminal law is at the expense of time allocated to the optional topics. Justice Kirby was critical ${ }^{61}$ of the emphasis that the 1988 syllabus placed upon criminal law because criminal law is only a small part of the operation of the law as such - and that was a criticism when criminal law was only an optional topic taking up approximately one-seventh of total course time. It is difficult to see why secondary school legal studies students will now be required to spend so much of their time on criminal law.

\section{THE 3 UNIT LEGAL STUDIES SYLLABUS}

The 3 Unit Legal Studies syllabus is for those students who are studying the 2 Unit subject and wish to study it in more depth. The 3 Unit syllabus "will enable students to deepen and strengthen the knowledge and skills of the 2 Unit syllabus". ${ }^{62}$ in an additional 60 hours of class time. As well as providing "an educational response to a growing societal need to know and understand ourselves, society and the role of law. ${ }^{63}$ the stated rationale of the course is "[t]o build upon the existing 2 Unit syllabus in Legal Studies and expand the students (sic) knowledge of the law at an International level."64

The 3 Unit syllabus aims to assist students to:

- participate as active citizens of Australia and the world;

- learn to value the importance of co-operation of peoples on an international level;

- understand the relationships between international law and domestic law;

- appreciate the important links between Australian domestic law and public international law;

- understand how international law has developed;

- understand and appreciate the limitations of international law;

- appreciate the functions and limitations of law in resolving conflict and regulating behaviour in society at an international 
level. ${ }^{65}$

As with the 2 Unit syllabus, the 3 Unit syllabus document contains a detailed list of objectives and outcomes with respect to knowledge and understandings, skills, attitudes and values. ${ }^{66}$ The stated objectives and outcomes illustrate the increased level of difficulty of the 3 Unit syllabus. For example, with respect to skills, it is envisaged that students should be able to use higher order forms of communication, use primary sources including treaties and cases, and demonstrate independence in research and in analysis. ${ }^{67}$

\section{Course Content}

The draft 3 Unit syllabus published in early 1993 required students to study two out of five modules with each module focussing on Australia in the international context.

The five modules were:

- The Challenge of World Order

- The Challenge of International Environmental Crises

- The Challenge of the Legal Position of Indigenous People

- The Challenge of the Legal Position of Displaced People

- The Challenge of Technology and change ${ }^{68}$

The focus of the course in on legal responses to global challenges. In each module students are expected to examine:

- historical perspectives

- the challenges to the legal system, and

- the practical and institutional ways in which the law is responding to the challenges. ${ }^{69}$

However, in the pilot syllabus to be implemented in 1994 students are required to study an introductory overview to international law ${ }^{70}$ and the following two compulsory modules:

- The Challenge of Global Environmental Protection

- The Challenge of Technological change ${ }^{71}$

Within each of the Modules there is a choice of four "Depth Studies" two of which must be studied. In Module 1 the Depth Studies are: The Marine Environment, The Atmosphere, Natural Resources and Wildlife. In Module 2 the Depth Studies are: MultiMedia Technology, Bio-Technology and Bio-Ethics, Communication Technology, and Technological Fraud. ${ }^{72}$ 


\section{Assessment}

Mandatory assessment weightings are given for each component of the course. ${ }^{73}$ The design of an assessment program is left to the professional judgement of teachers who must ensure that the selected assessment instruments cover both knowledge and skills for it is this assessment that is used to determine end of course achievement which forms the basis of the moderated Assessment Mark in Legal Studies. ${ }^{74}$ Students are also required to sit an HSC examination for the 3 Unit course for which they will be awarded a single mark out of 50 . The examination paper is to contain two sections corresponding to the two modules set out in the syllabus. Students must attempt two questions, one from each of the two sections. All questions require an essay type answer. ${ }^{75}$

If the 2 Unit course is ambitious then the 3 Unit course can only be described as overwhelming. As noted earlier, the survey of the 2 Unit course revealed that the most popular topics were Crime and the Law, the Family and the Law, Aborigines and Women. Students undertaking the 3 Unit course in 1994 will not be able to study any of these topics in more depth. Even when the 3 Unit course is fully implemented, students who wish to do the additional 3 Unit work will not be studying the 2 Unit topics in more detail but will apparently be doing a short course in international and comparative law. One cannot doubt the increased level of difficulty of the 3 Unit course when it includes such topics as the law of the sea and multilateral treaties, international instruments and agencies protecting technology, bioethics and genetic engineering and technological fraud. If the 3 Unit syllabus in its final form attempts any detailed analysis of these and the other topics within the abovementioned modules it will be difficult to imagine how teachers and students will be able to cope with the material. The course will undoubtedly put greater strain on teachers in terms of training and resources. The 3 Unit pilot syllabus document does not explain why it is that the syllabus committee decided that an understanding of the international dimensions of legal issues was essential for secondary school students who wished to study Legal Studies in more depth. Tertiary students can be awarded a Bachelor of Laws degree at most universities with perhaps one or two semesters of international law type subjects in their entire degree; it appears secondary school students interested in law will only get 
through HSC Legal Studies with one-third of their final grade determined by their achievement in the same type of subjects.

It is obvious that the Board of Studies approved the introduction of the 3 Unit pilot syllabus to meet a 1994 deadline because it is offering students only two of the five proposed modules. Students and teachers have therefore been left with no choice as to the topic areas they study. The 2 Unit optional topic the Environment and the Law, provides a good base on which to build further study in Module l. However, if students have not studied this topic at 2 Unit level, they will have difficulty understanding the material in the 3 Unit Module on Global Environmental Protection. It will be interesting to see how many schools and how many students actually take up the 3 Unit Course in 1994.

A further difficulty with the 3 Unit course will be finding texts to cover the range of topics that are at a level appropriate for secondary school students. The Board of Studies has however, published HSC Course Support Documents ${ }^{76}$ that appear to be interim texts. The course support documents have been compiled by the Board with the assistance of, inter alia, legal practitioners in private practice and university law school academics. They contain a lot of detailed information on the topics covered in the two compulsory modules. They also include references to a wide range of resources such as traditional legal texts, articles from law and other academic journals and unpublished conference papers. Fortunately, the resources referred to can be purchased from the Board of Studies. Whether these teaching materials are suitable and whether teachers and students will benefit from these materials remains to be seen.

\section{LEGAL STUDIES TEACHERS}

The responsibility for teaching the Legal Studies courses rests with secondary school teachers. Even though the focus of the courses is stated not to be on rules but on concepts and themes, they are still ambitious courses and still demand a specialist background knowledge and access to adequate and appropriate teaching materials and up-to-date information.

Unlike university academics who have traditionally been employed without any training in teaching, secondary school teachers have had at least one year of teacher training. 
Teachers have been trained to teach but now they are being called upon to teach a subject in which they may have very little or no formal background.

To ensure the success of the Legal Studies course it is essential that there are teachers equipped to do the work.

The 1992 survey of the 2 Unit course revealed some interesting facts about the teachers teaching it. The overwhelming majority of them were social science teachers $(85 \%)$ but there were a number of English/History teachers (13\%) and teachers from "other" disciplines, namely, 2 language teachers and 1 Home Economics teacher! Only 5\% of Legal Studies teachers had a law degree or diploma; ${ }^{77} 19 \%$ had studied law in their degree; $24 \%$ had experience in law from school in-services; and the majority of 39\% had no formal experience in law at all. The main reason given by teachers for teaching the course was interest (91\%); only 3\% chose to do it because of legal qualifications. "Legal Studies" conjures up a teacher who has a law degree but this is evidently not the case in New South Wales.

What type of qualifications should we require of Legal Studies teachers? Do we want "lawyers who can teach or teachers who are lawyers?"78

In 1979 Goldring noted that -

"Very little thought has been given to the qualifications of law teachers or to the training that should be available to them. Nor has there been much thought given to the relation between the aims of the various types of legal education and the best people to do the teaching."79

These issues have yet to be adequately addressed in the literature or by the relevant authorities.

Very few Legal Studies teachers have law degrees. Many would be trained in commerce or in economics and so may have completed a few courses in commercial law as part of their university degrees. But this type of legal training in a commerce or an economics degree is really "learning law" rather than a study of "the way the law works in society" 80 and so is totally inadequate training for a course based on concepts of justice, law and society.

Nevertheless,

"The success and the expansion of legal studies in schools suggests that those who are not lawyers can teach about law, though the depth and accuracy of their legal knowledge will in many cases be questionable."81 
Goldring argues that most lawyers are not suited to teaching law in schools because during the time it takes to get a law degree they are socialised into a professional subculture.

"A person who speaks and thinks legalese may find it hard to communicate with the students." 82

He therefore prefers teachers who are trained in law:

"Law teachers at secondary level ... should be teachers first ... ."83

Goldring's views are echoed in a newsletter ${ }^{84}$ where teachers are advised that they must observe the philosophy behind the syllabus and not teach a course that is pure law.

"Legal Studies is all about individuals interacting with each other and with groups, their rights and responsibilities and what happens when people neglect their responsibilities ... the very nature of the work undertaken by Social Science and History teachers provides the expertise to teach a subject relating to human relationships. Legal Studies is such a subject." 85

Furthermore, teachers are told not to be concerned if they do not have a law degree -

"Remember - few Law graduates could handle a mixed ability senior class in Legal Studies."

Yet, the teachers "cannot teach what they do not know."87 Teachers without sufficient knowledge of the law will not be able to satisfactorily deal with the material set out in the 2 Unit and 3 Unit syllabi. It is therefore essential that resources are made available and courses offered to teachers teaching the subjects.

What type of assistance is available to non-legally trained teachers to help them cope with the 2 Unit and 3 Unit Legal Studies courses?

\section{ASSISTANCE TO LEGAL STUDIES TEACHERS}

Given the need for some form of legal training for the teachers responsible for teaching the course, it is important to look at what sort of practical assistance is being given or being made available to Legal Studies teachers. There is a very wide range of sources of assistance - from the Department of School Education, the legal profession, the universities, teacher support groups etc. - but not all teachers are able to take advantage of this assistance because 
they are either not aware of it or physically unable to make use of it.

Department of School Education/Board of Studies At the time the 2 Unit course was introduced, the government authorities were criticised for their total lack of in-service programmes to assist getting the course to together and implementing the requirements of the syllabus. ${ }^{88}$ In 1989, the Board established an advisory body known as the Curriculum Implementation Consultative Group (CICG) to establish a support network to assist teachers. The CICG included one representative from each of the 10 regions in NSW who was trained to organise in-service courses and deal with problems faced by teachers in interpreting the syllabus. The regional representatives were given a lot of extra work with very little reward.

All the support from the centre ended when the CICG was suddenly disbanded at the end of 1990. It was left to other bodies to step in and provide in-service courses and activities. It appears that the only assistance coming now from the Board and/or the Department is in the form of a range of publications such as sample answers and support documents that are available to help teachers through the HSC examination. ${ }^{89}$ Unfortunately, these publications are not freely available but must be paid for by teachers or their schools.

What is left is the work of the regional Education Resources Centres that organise in-service courses on a regional basis, i.e. one day or half day seminars with guest speakers such as local Members of Parliament, local solicitors, etc.

\section{Teacher Support Groups}

What is also left is the work of the teachers' own support groups.

From the very beginning, teachers were advised not to work in isolation but to spend time establishing networks with colleagues teaching the course in order to encourage a "free and regular exchange of approaches, ideas on subject matter, successful lessons, and resources." 90 LETA first submitted the idea of a Legal Studies course to the Board but appears to have done very little to assist the implementation of the course in the classroom. LETA was started up again in 1992 and it may, through its newsletter, be a 
means of co-ordinating all the work being done by the various bodies.

A lot of work is being done by the Social Science Teachers' Associations. Not all regions in NSW have strong teachers' associations but those that do also organise in-service courses. The Metropolitan East Social Science Teachers' Association (MESSTA) is particularly active. With the support of the Law Society of New South Wales, MESSTA has organised annual statewide Legal Studies conferences for the last few years that have been going from strength to strength: from a one day seminar in 1990 to a two day conference in 1991 to two programs over two days in 1992 (one program for teachers teaching the subject for the first time and the other for experienced Legal Studies teachers). These conferences are designed to fill some of the gaps in teacher training and to give teachers practical advice on developing teaching materials and resource sharing. ${ }^{91}$ Conference papers are also published to meet the heavy demand by teachers for printed materials. Clearly, this sort of activity is essential to the success of the Legal Studies courses.

\section{The Legal Profession}

There are many potential resources available to teachers from within the legal profession generally and from the Law Society of New South Wales in particular. Again, for these resources to be of any real value, teachers must be made aware of them.

The Law Society sponsors a number of schemes designed to assist secondary school students and their teachers. The Speakers' Bureau supplies solicitor speakers on any legal topic to school and community groups; the annual Law Week activities include programs relevant to schools, e.g. Schools in Parliament project. ${ }^{92}$

The Law Society also organises the inter-school mock trial ${ }^{93}$ competition which has become an important part of many schools' legal studies activities. Interest in the competition grows each year; it began with 28 teams in 1981 and there were almost 400 teams in 1992. ${ }^{94}$ The competition complements the syllabus by showing students how the legal system operates through their actual participation in the "trial" and by developing their public speaking skills. Nevertheless, despite the success of the competition, participation is necessarily limited; only a few students actually 
appear and argue the case, not the entire class group.

The Law Society assists with the production of teaching aids for schools by publishing Legal Eagle, a quarterly publication in newspaper format that focuses on issues relevant to the syllabus. Teachers have indicated that Legal Eagle is "relevant, informative and useful as a secondary school resource."95

Whether or not there is a formal scheme in place, many solicitors will find themselves being asked to speak to school students, particularly as Legal Studies grows in popularity. ${ }^{96}$

\section{Legal Publishers}

Books for non law school students have, until recently, been ignored by the leading legal publishers. However, this situation has certainly now changed with a flood of new and revised books on the market specifically designed to meet the needs of the new target audience, that is, the secondary school Legal Studies students.

Butterworths had the first textbook on the market based on the New South Wales syllabus; it was a "trailblazer — the text that others followed." 97 That text was quickly followed by a second edition that included some chapters that were completely re-written in light of the demands of the syllabus and the HSC exams. ${ }^{98}$

Other publishers quickly followed Butterworths' lead, keen to enter the new and expanding market. ${ }^{99}$ These texts are being written by a variety of authors: legal practitioners, university academics, senior teachers. It appears that as the Legal Studies course is becoming more settled, teachers are making a greater contribution to the content of the texts.

In addition to textbooks, the legal publishers are now also publishing study guides and teaching aids such as videos that complement the texts. ${ }^{100}$

\section{The Universities}

Certainly the universities can offer much to Legal Studies teachers to address the issue of teacher training and qualifications. The University of Sydney, ${ }^{101}$ for example, runs a series of evening lectures based on the Legal Studies syllabus especially for teachers. Macquarie University also has a course in its Continuing Education Program designed to assist Legal Studies teachers in becoming 
more confident with legal concepts and in developing lesson plans, strategies and resources. This is a start, but clearly is not enough. ${ }^{102}$ A postgraduate course specifically designed for Legal Studies teachers would be ideal but may face the problem of attracting sufficient numbers to make the course economically viable.

There should be demand for such a course as there appears to be a great need for it. However, demand will not necessarily be high. Apart from the problem of the fees payable for such a course, which would have to be met by the individual teachers concerned, is the problem of the unwillingness to make a commitment to further study given the uncertainty of teaching loads; teachers who are teaching Legal Studies this year are not guaranteed that they will teach it next year or indeed, ever again. It appears that short courses or a series of lectures are the preferred option, at least in the short term.

The universities should be doing much more. Le Brun and Clark suggest a number of formal and informal strategies to build a working partnership between tertiary and secondary legal educators. ${ }^{103}$ Moreover, they argue the relationship between the schools and the universities "must of necessity be reciprocal and respectful of the special needs of each. ${ }^{104}$

"While the tertiary level educator often has valuable expertise in subject
matter, many tertiary educators have little or no formal training in
education. Accordingly, there is much about pedagogical technique and
educational theory and practice which the tertiary educator can learn
from colleagues at secondary level, many of whom have a wealth of
experience and professional training in teaching."105

So, there should be an exchange of expertise in subject matter for expertise in teaching. It must be remembered that university law lecturers and secondary school legal studies teachers are both legal educators; the size of the class and the abilities of the students may be different, as may be the purpose of the class, but "we are all in the same boat". ${ }^{106}$ Le Brun and Clark call for more research to be done on the relationship between secondary and tertiary legal education to ensure courses are complementary and to consider how the completion of secondary school courses may affect the curriculum taught and pedagogical approaches adopted in first year law study at university. ${ }^{107}$ 


\section{Miscellaneous}

Teachers can also seek assistance from other sources. The Legal Information Access Centre ("LIAC"), a joint project of the State Library and the Law Foundation of New South Wales, was set up to help people without access to law libraries; this includes, but is not limited to, Legal Studies teachers and students. LIAC provides information about the law, texts, dictionaries, leaflets, Acts, regulations, cases, videos, etc., and publishes a quarterly newsletter that includes a column dedicated to the Legal Studies course. LIAC also organises library tours for student groups with an emphasis on developing basic legal research skills. LIAC staff have noted that one of the main problems facing teachers is that many of them are simply not aware of all the resources that are available that may be useful to them. Those that are aware of LIAC complain that it is not convenient; information will only be given over the telephone to teachers outside the metropolitan area - others have to go in to the library at the only practical time which is on weekends.

The John Fairfax organisation has an Education Unit that provides clippings kits for a number of secondary school subjects, including Legal Studies. These kits are a collection of relevant newspaper articles related to course content; particularly useful as this sort of exercise is often included as an assessment task for students.

\section{Conclusion}

There is no doubt that Legal Studies deserves a place on the secondary school curriculum in New South Wales. However, in order for it to be an educational success, it is essential that the aims and the objectives of the course are realistic and that the content is kept within reasonable limits. This does not appear to be the case, particularly with the 3 Unit course. Furthermore, it is also essential that adequate training is provided to teachers given that the majority of them have very little or no background in law before taking a Legal Studies class. This training is currently available from a variety of different sources and therein lies the major problem with respect to teacher training: it is not centralised. The Board/Department determine the syllabi and set and mark the HSC 
examinations, yet they do not organise or even coordinate all the assistance currently available to teachers. How do they ensure that all teachers - and teachers outside the Sydney metropolitan area in particular - have the appropriate level of knowledge to cope with the demands of the Legal Studies courses? As discussed above, teachers and others are doing a lot of work themselves on a regional basis. However, what is also needed is some form of central quality control. With the introduction of the 3 Unit course it is hoped that more is done to assist teachers with the subject matter of the course so that teachers can concentrate on teaching rather than putting most of their efforts into acquiring new substantive knowledge.

* Sydney University, Faculty of Economics, Lecturer in Commercial Law.

1 Indeed, the Centre for Legal Education recently established by the Law Foundation of New South Wales holds material on tertiary legal education only.

2 See: J Edwards, In Defence of Legal Studies (1986) 60 Law Institute Journal 190, at 191; M Kirby, Introduction, in S Churchman, M White, H Williams Rights and Wrongs Legal Studies for Senior Students, Volume 1, (Sydney: CCH, 1992) at. viii; M Kirby, Teaching the Law is an Asset (1983) 18 Education News (No 5) 16, at 18; Note, Legal Studies in Secondary Schools (1979) 53 ALJ 475; and PJ Fitzgerald, Law at School — A Canadian Viewpoint (1978) 128 New Law Journal 300.

3 See further: DRC Chalmers \& E Clark, Legal Studies for Tasmania, 3rd ed (Sydney: Butterworths, 1992) at ix; MJ Le Brun \& EE Clark, The Growth of Legal Education in Australian Secondary Schools: Implications for Tertiary and Secondary Legal Education (1989) 1 Legal Education Review 217, at 218; Kirby, supra note 2, at 17-18.

4 See: MJ Le Brun, Reflections on Legal Studies Courses in Australian Secondary Schools: Instrument or Liberal Education (1990) 12 Adelaide Law Review 389, at 406; and WL Twining, Legal Education for All in DW Mitchell (ed.) Papers on Legal Studies and Legal Education for Non-Lawyers (Butterworths, 1979) at 12 where Twining claims that the academic legal tradition has something special to offer for its modes of reasoning and analysis "are not unique to law, but are merely particular applications of practical reasoning in general and of certain basic human skills, such as skills of rule handling, of spokesmanship and thinking in terms of process and procedure".

5 ES Magner, The Development of Australian Law, in Committee for Postgraduate Studies Legal Studies in Secondary Schools (Department of Law University of Sydney, 1991) at 1.

M Kirby, supra note 2, at 18.

Le Brun, supra note 4, at 394-396.

8 AP Dobson, Law Should be Taught in School (1977) 127 New Law Journal 875, at 875:

... Mr. Average has never heard of the word 'tort'. He is unaware of the existence of an institution called the county court. ... To him a contract is a piece of paper, a document and it has no meaning wider than that ... and he has no conception of the role of our judges in making law whether by extending the common law or in interpreting statutes. These are just examples of what I perceive to be a general public ignorance.

9 KE Lindgren, Legal Studies in Australian Secondary Schools - An Account 
and Some Issues (1980) $54 A L J$ 399, at 399. This fear is not well founded as most legal studies teachers are very conscious of their need of support from the legal profession.

Edwards, supra note 2, at 191.

Dobson, supra note 8 at 875.

Ibid.

13 Twining, supra note 4, at 6 .

14 Ibid. See also: Fitzgerald, supra note 2, at 300 and M Whincup, What Should be Taught in School? (1977) 127 New Law Journal 1020, at 1021.

15 Kirby, supra note 2, at vi.

16 Note, supra note 2, at 475.

17 Lindgren, supra note 9 , at 400.

18 Ibid.

19 J Bowen, Raising Community Understanding of the Law and Lawyers (1986) 24 Law Society Journal at 57.

20 D Roberts, Legal Studies a Teacher's Guide (Sydney: Butterworths, 1992) at 2. In fact, 6,893 school students and 214 TAFE and other students sat the 1991 HSC exam. These figures represent approximately $13 \%$ of all HSC candidates for that year. See: Board of Studies New South Wales, 1991 Higher School Certificate Examination Statistics (Sydney: Board of Studies, May 1992). Victoria is the acknowledged leader in teaching law and law related subjects in secondary schools. This article will deal only with Legal Studies in New South Wales secondary schools. For developments in other States see: Note, Community Legal Education and Teaching of Law in Australian Schools (1979) 53 ALJ 742; ICE Lindgren, Legal Studies in Australian Secondary Schools An Account and Some Issues (1980) 54 ALJ 399; M Kirby, Teaching the Law is an Asset (1983) 18 Education News 16; Note, Legal Studies in Queensland (1988) 13 Legal Service Bulletin 38; J Edwards, "In Defence of Legal Studies (1986) 60 Law Institute Journal 190; MJ Le Brun \& EE Clark, The Growth of Legal Education in Australian Secondary Schools: Implications for Tertiary and Secondary Legal Education (1989) 1 Legal Education Review 217.

21 Board of Secondary Education New South Wales, 2 Unit Legal Studies Syllabus Year 11-12, (Sydney: NSW Department of Education, 1988) at 3.

22 J Goldring, Legal Studies in New South Wales Schools (1988) 13 Legal Service Bulletin 215, at 215.

23 Board of Secondary Education New South Wales, supra note 21, at 5. It is interesting to note that in the July 1991 introduction to the HSC Sample Answers, the Board listed the same 5 aims but in a different order, i.e. what is first on the list in the syllabus is last on the 1991 list. Does this suggest a change in emphasis in the two years of operation of the course?

24 Id at 7-9.

25 Id at 8. These objectives do not appear to be consistent with the stated rationale of the course.

26 C Diekman, Legal Essentials Understanding Australian Law (Sydney: Oxford University Press, 1991) at 5-6.

27 Board of Secondary Education New South Wales, supra note 21, at 14.

28 S Churchman, M White, H Williams Rights and Wrongs Legal Studies for Senior Students Volume 1, (Sydney: CCH, 1992) at iv.

29 Board of Secondary Education New South Wales, supra note 21, at 11.

30 Diekman, supra note 26, at 3.

31 Board of Secondary Education New South Wales, supra note 21, at 11-12.

32 L Boyd, Resources Handbook: A Guide to Legal Studies for New South Wales Years 11 and 12 (Sydney: Butterworths, 1989) at 3. 
Board of Secondary Education New South Wales, supra note 21, at 11.

Roberts, supra note 20, at 3.

Board of Secondary Education New South Wales, supra note 21 at 15-22.

Id at 23-28.

Id at 29-36.

Id at 37-44.

Id at $45-50$

Id at $51-56$

Id at $57-62$.

Churchman et al, supra note 28, at iv.

The groups are: Aborigines, migrants, the disadvantaged and women.

Churchman et al, supra note 28, at iv.

Kirby, supra note 2 at vii.

Board of Secondary Education New South Wales, supra note 21, at 64.

Board of Studies New South Wales, 1990 HSC Sample Answers 2 Unit Legal Studies (Sydney: Board of Studies, July 1991) at vi.

Board of Studies New South Wales, 1992 Legal Studies Higher School Certificate Examination (Sydney: Board of Studies, November 1992), Question 21.

4 Assessment components and weights: knowledge 40\%; critical and analytical skills 30\%; observation and research skills $15 \%$; communication skills $15 \%$. See: Board of Secondary Education New South Wales, Legal Studies Specimen Paper and Support Documents (Sydney: NSW Department of Education, March 1989) and Board of Secondary Education New South Wales, supra note 21, at 81.

Le Brun, supra note 4, at 423-424.

D Roberts, Countdown to the Big Day, The Northern Daily Leader, 22 September 1992.

Le Brun, supra note 4, at 419.

Ibid.

K Ford, 2-Unit Legal Studies Syllabus Review Summary of Responses (Assessment Unit, Board of Studies New South Wales, 1992).

Board of Studies New South Wales, Legal Studies Syllabus 2 Unit Preliminary and HSC Courses, (Sydney: Board of Studies, October 1993) at 6.

120 hours is to be allocated to the Preliminary Course and a further 120 hours to the HSC course.

Id at 5-6.

Id at 28 and at 84 .

Id at 84 .

Interestingly, the three parts of this topic are to be done in a different order in the revised syllabus. The order is: i) The individual and the State; ii) Case studies; iii) The nature of law and justice.

Crime and the Law (48 hours) + Effectiveness of Criminal Law (12 hours) $=$ Total 60 hours. As an optional topic in the 1988 syllabus, Crime and the Law was allocated one-seventh of total course time (i.e. approx. 34.5 hours)

Kirby, supra note 2, at vii.

Board of Studies New South Wales, Legal Studies Pilot Syllabus 3 Unit Preliminary and HSC Courses, (Sydney: Board of Studies, November 1993) at 1.

Id at 2.

Ibid. 

Technological Change HSC Course Support Document (Sydney: Board of Studies, 1994); Board of Studies New South Wales, Legal Studies 3 Unit The Challenge of Environmental Protection HSC Course Support Document (Sydney: Board of Studies, 1993).

77 Interestingly, in Tasmania one-fifth of Legal Studies teachers surveyed in 1988 held formal qualifications in law. Le Brun \& Clark, supra note 3, at 226. competitions, etc.

A mock trial is a simulated legal case in which teams contest a fictional legal matter in the mock local/district court. Teams are coached and judged by legal practitioners. Society Journal, February 1992, at 54.

Bowen, supra note 19, at 57.

Assistance is generally available from legal bodies as to how solicitors should speak to schoolchildren. See: M Hayden, A Guide for Solicitors Addressing Groups of Students (1988) 13 Legal Services Bulletin 215.

97 R . Duncan (ed.) Legal Studies for New South Wales Years 11 and 12 (Sydney: Butterworths 1989) Butterworths also publishes texts for each State based on the syllabus in each State. 
RM Duncan \& D Roberts, Legal Studies for New South Wales, 2nd ed (Sydney: Butterworths, 1992).

99 CCH: S Churchman, M White \& H Williams, Rights and Wrongs Legal Studies for Senior Students Volume 1 and Volume 2, 1992; M White \& L Tan, Legal Studies Casebook, 1990; Landmark Series from 1980 (summaries of important High Court cases). Oxford University Press: E Ellis, J Goldring \& C Diekman, Society Law and Justice Legal Studies for Senior Students, 1992. Longman Cheshire: M Parker and B Derwent, Justice Law and Society, Volume 1 and 2, 1991.

100 See: C Diekman, Legal Essentials Understanding Australian Law, (Sydney: Oxford University Press, 1991) B Pickworth and J Pickworth, Passing HSC Legal Studies: A Guide for Students and Teachers, (Sydney: Butterworths, 1991) D Roberts, Legal Studies A Teacher's Guide, (Sydney: Butterworths, 1992) L Boyd, Resources Handbook: A Guide to Legal Studies for New South Wales, Years 11 and 12, (Sydney: Butterworths, 1989) B Brassil, Excel HSC Legal Studies, (Sydney: Pascal Press, 1992).

101 Committee for Postgraduate Studies in the Department of Law.

102 Only teachers in the Sydney metropolitan area can attend these evening lectures and meetings, so a large percentage of teachers are simply not able to enjoy the benefit of these classes. Both programs are fee paying programs.

103 Le Brun \& Clark, supra note 3, at 231.

104 Id at 230.

105 Ibid.

106 E Magner, supra note 5, at 1.

... we are all teachers. I teach this material to the students who have enrolled for a law degree at The University of Sydney. My "class" is held in a lecture theatre that holds $300 \ldots$ it numbers 240 and my students intend to become lawyers and have achieved high TERs in order to get where they are .. you are teaching ... to ... groups no larger than 25 . Your students are primarily being educated to be informed citizens, users rather than providers of legal services, and of course your students have a much wider range of abilities.”

107 Le Brun \& Clark, supra note 3, at 217. 